\title{
Does Singular and Stacked Corn Affect Choice Behavior for Oviposition and Feed in Spodoptera frugiperda (Lepidoptera: Noctuidae)?
}

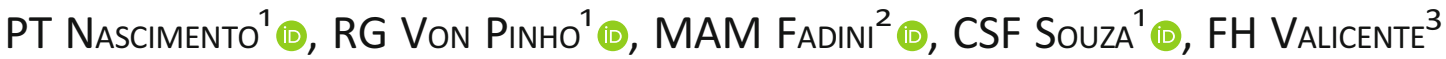 \\ ${ }^{1}$ Univ Federal de Lavras - UFLA, Lavras, Brasil \\ ${ }^{2}$ Univ Federal de São João del-Rei - UFSJ, Sete Lagoas, Brasil \\ ${ }^{3}$ Empresa Brasileira de Pesquisa Agropecuária - Embrapa Milho e Sorgo, Sete Lagoas, MG, Brasil
}

\section{Keywords}

Transgenic crops, reproductive performance, fall armyworm, insect-plant interaction

\section{Correspondence}

F.H. Valicente, Empresa Brasileira de Pesquisa Agropecuária - Embrapa Milho e Sorgo, Sete Lagoas, MG, Brasil; fernando. valicente@embrapa.br

Edited by Jorge B Torres - UFRPE

Received 5 August 2019 and accepted 12 December 2019

Published online: 22 January 2020

(C) Sociedade Entomológica do Brasil 2020

\begin{abstract}
Little is known about the effects of genetically modified corn plants on the foraging of Spodoptera frugiperda (J.E. Smith). Therefore, this study examines whether singular herbicide-tolerant and insect-resistant plants and their stacked events interfere with food preference and oviposition of S. frugiperda. Two non-Bt corn hybrids and three Bt-hybrids, some of them with glyphosate tolerance (GT), were evaluated. Food preference of larvae and biological parameters were assessed. Oviposition preference bioassays involved choice and no choice condition in plants uninfested and previously infested by larvae in a greenhouse and in the field. The results indicate that there is no relationship between preference of larvae and adult moths. Adult females selected preferentially transgenic hybrids, while larvae selected non-Bt hybrid. Fall armyworm larvae avoid Bttoxin-expressing leaf tissues, survived only on the non-Bt leaf tissues, and showed minor differences in other life-history traits reared on GT and non-transgenic corn leaf tissues. Female moths showed preference for transgenic plants to lay eggs, but with variable output between previously infested and uninfested plants with larvae. The fact that moths preferred Ag 3700RR2 and non-Bt hybrids for oviposition supports the refuge's strategy aiming at producing susceptible individuals. The use of this hybrid must be integrated with a program of control. The results showed also the importance of correct hybrid selection as part of insect resistance management to Bt-plants. The implications of these findings for understanding the impacts of plant-mediated cues on pest behavior in transgenic crop systems are discussed.
\end{abstract}

\section{Introduction}

Females use chemical receptors that detect plant odors for feeding, oviposition, and the presence of conspecifics (De Moraes et al 2001, Signoretti et al 2012). Host plant selection by herbivorous insects fundamentally affects their offspring's survival and reproduction, and is particularly relevant to neonate offspring because they are especially susceptible to plant defenses, and must cope with a variety of obstacles to successfully colonize a host (Refsnider \& Janzen 2010). Further, oviposition by lepidopteran species is affected by factors such as secondary vegetal chemical products (Udayagiri \& Mason 1995), phenological stages, plant morphology, and physiological conditions (Bestete et al 2016, Bestete et al 2017).

Although adulthood is the primary stage in life for the dispersion of most lepidopteran species, the larvae of several species disperse at the original oviposition site and seek other 
host plants within a limited space (Carriere 1992, Zalucki et al 2002). Adult females of Spodoptera frugiperda (J.E. Smith) (Lepidoptera: Noctuidae), for example, may lay up to 200 eggs per egg mass (Pitre et al 1983). Thus, larvae neonated often disperse from the oviposition site to decrease intraspecific competition and avoid cannibalism (Bellota et al 2017), action of natural enemies, and depletion of food sources (Singer \& Stireman 2001, Singer \& Stireman 2003), hence limiting exposure to toxins (Singer et al 2002) or compensating oviposition choices by females (Doak 2000).

Among the insect pest control tactics, the use of transgenic plants has been used worldwide (Schuler et al 1999). The use of transgenic crops, such as those that produce insecticide proteins from the bacterium Bacillus thuringiensis (Bt), offered an efficient tactics for pest management, which soon became an important strategy (Storer et al 2012). Multiple Cry proteins were combined in genetically modified plants to widen targets, delay the evolution of pest resistance, and simplify crop management (Head et al 2017). Further, plants with multiple characteristics, such as herbicide tolerance and insect resistance, have become relevant (Isaaa 2018). Hybrids with stacked events are currently available with the insertion of one or more proteins Cry besides herbicide tolerance, coupled to plants with single events, which exhibit either insecticide protein or herbicide tolerance (Isaaa 2018).

Due to intensive use of Bt technologies and mainly due the adoption to stacked events, the evaluation of these technologies is crucial to investigate whether these hybrids influence the foraging behavior of herbivores. The current paper discusses whether singular and stacked corn events interfere in the feeding of larvae and oviposition of S. frugiperda females.

\section{Materials and Methods}

\section{Greenhouse plant cultivation}

This study was conducted using two non-Bt corn hybrids and three Bt-hybrids, some of them with glyphosate tolerance (GT). The Bt-corn hybrids had the same genetic background of the no-transgenic isoline corn (DKB39o hybrid, harvest 2016), and expressed the following proteins: Cry1A.105/ Cry2Ab2 (VTPRO technology, hybrid DKB390, harvest 2016), Cry1A.105/Cry2Ab2/GT (VTPRO2 technology, hybrid DKB390, harvest 2016), Cry1A.105/Cry2Ab2/Cry3Bb1/GT (VTPRO3 technology, DKB390 hybrid, harvest 2016), In addition, a non-Bt, glyphosate-tolerant corn (RR2 technology. Ag 3700 hybrid, harvest 2016) from Dekalb (Monsanto, St. Louis, USA), was used.

The hybrids were planted in 2-L polyethylene pots filled with $1.5 \mathrm{~kg}$ of soil. Maize plants used in the bioassays had been growing for 10-12 days after emergence and had three fully expanded leaves (V3), in which plants are naturally attacked by S. frugiperda (Cruz \& Turpin 1982). Plants were kept in greenhouse $\left(25 \pm 5^{\circ} \mathrm{C} ; 70 \pm 15 \%\right.$ UR; $\left.14 \mathrm{~h}\right)$, and irrigated every other day. Field experiments were conducted in Nova Porteirinha, State of Minas Gerais, Brazil (15 $48^{\prime} 15^{\prime \prime S}$; $43^{\circ} 18^{\prime} \mathrm{O}$ "W; altitude $518 \mathrm{~m}$ ).

Insects

The insects were obtained from laboratory rearing in which the larvae fed on an artificial diet (Valicente \& Barreto 2003), and adults were fed with an aqueous honey solution (25 g sugar; $1 \mathrm{~g}$ ascorbic acid; $1 \mathrm{~g}$ corn glucose in $1.000 \mathrm{~mL}$ distilled water). The laboratory rearing was initiated using larvae collected from corn field (no-transgenic hybrid BRS1030) at Embrapa Milho e Sorgo, Sete Lagoas, State of Minas Gerais, Brazil, in 1980, and annually the colony has been supplemented with larvae collected from the same area. These larvae lack any resistance to Cry toxin. Insect rearing was conducted according to Valicente \& Barreto (2003). The insects were kept under controlled conditions in the laboratory $\left(25 \pm 1^{\circ} \mathrm{C} ; 70 \pm 10 \%\right.$ UR, $\left.12 \mathrm{~h}\right)$.

\section{Biology of S. frugiperda in non-Bt corn}

Isoline and RR2 corn hybrids were evaluated. Seeding was performed in the field with conventional crop treatments. Plants with six to eight completely developed leaves were selected; the leaves were harvested, washed in tap water, and prepared for the tests. Newly hatched larvae $(<24 \mathrm{~h})$ were placed in 50-mL plastic cups and covered with acrylic lids at rate of one larva per cup. Three sections of tender leaves with approximately $6 \mathrm{~cm}^{2}$ were used for each corn hybrid. Leaves were replaced every 2 days until the end of the larval stage. Weight of 10-day-old larvae, weight of pupae, and duration (days) of larval stage (first to sixth instar) were tallied. Larvae and pupae weights were taken using a precision scale weight measure $(1 \mathrm{mg})$. One replicate was considered the average of 24 larvae. Assays were performed in a completely randomized design, with 4 replicates, with 96 individual larvae for each hybrid. Assays were performed in a laboratorycontrolled conditions at $\left(25 \pm 2^{\circ} \mathrm{C} ; 70 \pm 10 \%\right.$ UR; $\left.14 \mathrm{~h}\right)$.

\section{Feeding preference of $\boldsymbol{S}$. frugiperda}

When plants had between six and eight completely spread leaves, they were transferred to the laboratory for cleansing and tests. The newest completely spread leaf was selected for tests. Ten first instar larvae were placed on Petri dishes (diameter $15 \mathrm{~cm}$ ), with one non-transgenic and one transgenic corn leaf (diameter $2 \mathrm{~cm}$ ). A thin layer of agar was poured in the plate bottom to lay the leaf section to maintain their turgor. The two leaves were kept $2 \mathrm{~cm}$ apart and larvae were introduced in the middle of the plate. The choice of larvae 
towards leaves was performed after $24 \mathrm{~h}$ of caging. The following combinations were assessed: VTPRO vs. isoline, VTPRO2 vs. isoline, VTPRO3 vs. isoline, and RR2 vs. isoline. Assay was performed in a completely randomized design, with four treatments and 30 replicates. Tests were performed in controlled conditions $\left(25 \pm 2^{\circ} \mathrm{C} ; 70 \pm 10 \%\right.$ UR; $14 \mathrm{~h}$ ).

\section{Survival test}

Corn hybrids (VTPRO, VTPRO2, VTPRO3, RR2, and isoline) were evaluated. Seeding was performed in the field with conventional crop treatments. Trials were initiated when plants had 3 to 10 completely expanded leaves. In the field plants were selected. The leaf preparation followed the same procedure adopted in the "Feeding preference of S. frugiperda" bioassay. Recently hatched larvae $(<24 \mathrm{~h})$ were placed one by one in 50-mL plastic cups and covered with transparent acrylic lids. One section of tender leaves with approximately $6 \mathrm{~cm}^{2}$ was used for each hybrid. Leaves were replaced every day until the end of the larval stage. Evaluations were run daily, and the percentage of survival from larvae to adult was assessed. Each replicate consisted of 24 larvae (96 larvae per treatment). This experiment was conducted in controlled laboratory conditions $\left(25 \pm 2^{\circ} \mathrm{C}, 70\right.$ $\pm 10 \%$ UR; $14 \mathrm{~h}$ ).

\section{Calculation of leaf area consumption}

The extent of damage caused by larval feeding on corn plants was determined by measuring leaf area consumption (LAC). The experiments were carried out in a greenhouse. The tests were conducted with plants in pots, when reached three fully expanded leaves $\left(V_{3}\right)$. The preparation of plants damaged followed the same procedure adopted in the "Tests for oviposition preference in damaged plants" bioassay. After treatment of infestation, the cage containing larvae was removed, and the leaf was sectioned. LAC was estimated using an LI$3100 \mathrm{C}$ leaf area meter (LI-COR ${ }^{\circledR}$ ).

Assays on oviposition preference in greenhouse

\section{Non-choice test}

Cages ( $0.7 \mathrm{~m}$ wide $\times 0.7 \mathrm{~m}$ long $\times 1.0 \mathrm{~m}$ high) were made of wood and covered with voile. In the center of the cage, only one vase of each hybrid tested was placed. Next, two 3-dayold mated females were released into the cage. After two scotophases, plants were removed from the cage for evaluation. The egg mass per plant were counted. The experiment was conducted in a randomized design with 12 replicates, where each cage with one vase corresponded to one repetition. The plants used were in stage $V_{3}$.
Multiple-choice test

Bt hybrids VT PRO, VT PRO 2, VTPRO3, RR2, and their isolines were distributed equally within the cages $(0.7 \mathrm{~m}$ wide $\times 0.7 \mathrm{~m}$ long $\times 1.0 \mathrm{~m}$ high), five treatments with multi-choice were assayed per cage with one plant of each hybrid. Ten 3-day-old adult mated females of $S$. frugiperda were released, and plants were removed from the cages after two scotophases exposure period for assessment. The number of egg masses per plant was registered. Tests were performed in a completely randomized design. Each set of plants formed a replicate $(n=12)$.

\section{Tests for oviposition preference in damaged plants}

Mated S. frugiperda females were exposed to corn plants for oviposition choice when containing previous larvae damage. Plants damaged were retrieved as follows: two clip cages, $3.5 \mathrm{~cm}$ diameter, with five third-instar larvae each, were locked to the plants. Infestations occurred from 08:00 a.m. to 02:00 p.m., for $6 \mathrm{~h}$ per plant (Signoretti et al 2012). After the infestation period, larvae were removed from the plants for tests. The plants were then placed in the cages. At 04:00 p.m., the females were released in the cages and left there for $48 \mathrm{~h}$. Plants were then removed for recording the egg masses present. Bioassay was replicated twelve times in the greenhouse at controlled conditions $\left(25 \pm 5^{\circ} \mathrm{C} ; 70 \pm 15 \%\right.$ UR; $14 \mathrm{~h}$ ). Non-choice and choice tests damaged plants were performed. In the non-choice tests, only one hybrid damaged was evaluated each time. In the multiple-choice tests, all hybrids damaged were distributed equidistantly inside the cages.

\section{Test for oviposition preference in the field}

The corn hybrids were submitted to field tests to evaluate whether field response would match to those performed in the greenhouse. Two assays were prepared. The first assay, without restriction in choice, comprised the sowing of all hybrids in a randomized complete block design (RCBD) (Fig 1), with four replicates. In the other experiment, with restriction in choice, the hybrids were cultivated in a RCBD, with four replications (Fig 2). Assessed hybrids in both assays were planted in 10 rows, measuring $10 \mathrm{~m}$ in length, with $0.70 \mathrm{~m}$ between the rows, with 5 plants $/ \mathrm{m}$ of row. Two middle rows were used, and plants were surveyed in the field. The number of egg masses was recorded, and the cultivation followed standard agronomic practices. Planting occurred on November 7, 2018, with two evaluations, on the 21st (phenological stages $-V_{3}$ ) and 28th (phenological stages $-V_{4}$ ) November 2018. Spraying with herbicide Primestra Gold $^{\circledR}$ (composition: $370 \mathrm{~g} / \mathrm{L}$ Atrazine $290 \mathrm{~g} / \mathrm{L} \mathrm{S}$ Metolachlor) occurred after planting. Assay employed $\mathrm{RCBD}$, with four replications. 


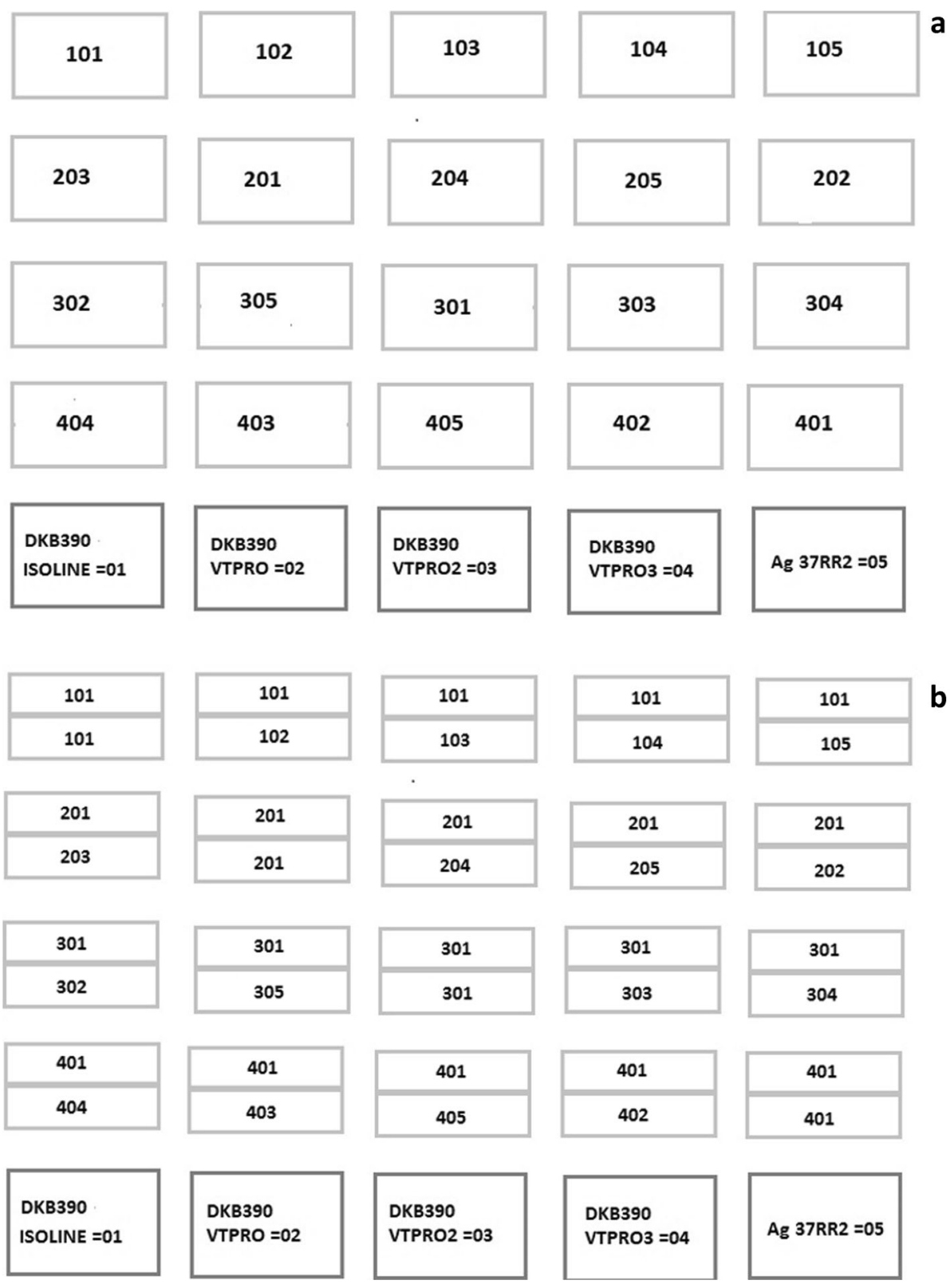

Fig 1 Field design used for oviposition preference: (A) assay without restriction, and (B) assay with restriction.
Fig 2 Survival (\%) of Spodoptera frugiperda (mean $\pm \mathrm{SE}$ ) fed on isogenic DKB39o, RR2, VTPRO, VTPRO2, and, VTPRO3. Averages followed by the same letter do not differ by the Tukey test at $5 \%$ probability.

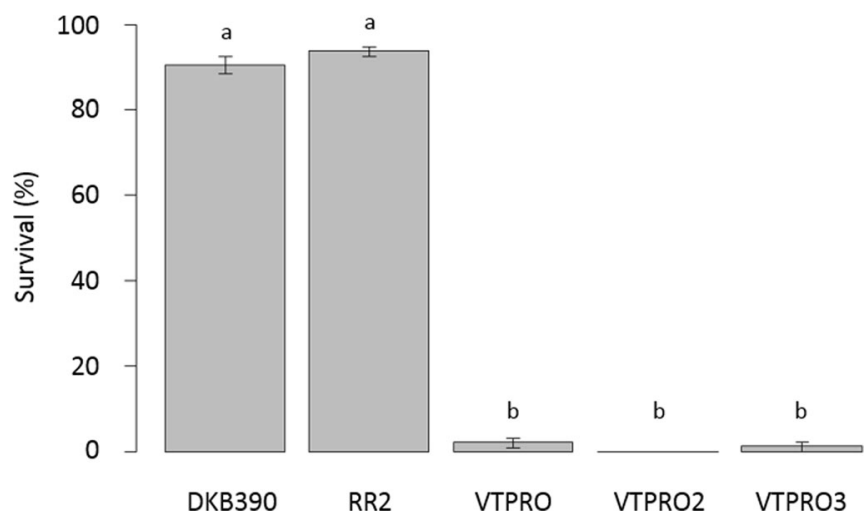




\section{Statistical Analyses}

The weight gain (g), larval period (days), weight of pupae (g), survival (\%), and number of egg masses of $S$. frungiperda were analyzed by analysis of variance (F-test, ANOVA) and mean separation performed with Turkey's test, when necessary, at 0.05 significance levels (Crawley 2013). All ANOVA assumptions were observed and, when necessary, square root $(x+1)$ transformation data was used to homogenize the variances. Residual analysis was used to evaluate the adjusted models (Crawley 2013). Feeding preferences of larvae were analyzed with $\chi^{2}$-test for categorical data, at $0.05 \%$ probability (Crawley 2013). Analyses, graphicals, and figures were performed using software $R$ using the basic packages ( $R$ Core Team 2014, version 3.5.3).

\section{Results}

Biology of S. frugiperda in non-Bt hosts and survival test

Isoline and RR2 did not affect gain weight $\left(F_{1,190}=1.80, P=\right.$ $0.18)$. However, the hybrids produced variation for larval period $\left(F_{1,154}=8.51, P<0.01\right)$, weight of pupae $\left(F_{1,119}=9.35\right.$, $P<0.01$ ), and survival (Fig 2, Tukey, $F_{4,15}=5.657$, $P<0.001)$. Therefore, the performance of $S$. frugiperda on these two hybrids was affected.

\section{Food preference of $\boldsymbol{S}$. frugiperda}

Spodoptera frugiperda preferred to feed on the hybrid isoline when compared with Bt-hybrids, but there was no significant score when compared with non-Bt transgenic RR2 (Fig 3).
Leaf area consumption

The amount of plant tissue consumed by $S$. frugiperda larvae varied between hybrids $\left(F_{4,100}=8.958, P<0.001\right)$. The hybrid RR2 (remaining area, $14.39 \mathrm{~cm}^{2}$ ) and isoline (remaining area, $13.01 \mathrm{~cm}^{2}$ ) showed higher LAC compared with $\mathrm{Bt}$ hybrids. Nonetheless, there were no significant differences in LAC between Bt-plants, VTPRO (remaining area, $19.52 \mathrm{~cm}^{2}$ ), PRO2 (remaining area, $20.02 \mathrm{~cm}^{2}$ ), and PRO3 (remaining area, $22.33 \mathrm{~cm}^{2}$ ).

Oviposition preference in greenhouse

\section{Non-choice test}

The studied factors regarding plant previously damaged by larvae and tested hybrids caused variation on host selection (hybrid: Fig $4(\mathrm{~A}), F_{4,55}=2.71, P<0.01$; and damaged: Fig 4(A), Tukey, $\left.F_{4,55}=12.80, P<0.001\right)$. In the non-choice test, undamaged plants, the hybrid VTPRO2 showed the lowest number of egg masses, indicating less preference by the moth. In contrast, the singular hybrid RR2 was the most preferred one, showing greater number of egg masses. In the case of damaged plants, moths preferred to oviposit in transgenic hybrid RR2, stacked VTPRO3 and in the hybrid isoline. In this test, VTPRO and VTPRO2 presented lower number of egg masses per plant than the other hybrids.

\section{Choice test}

In the choice bioassay the hybrid (Fig $4(B), F_{4,55}=5.32$, $P<0.001$ ) and damaged (Fig $4(B), F_{4,55}=20.83, P<0.001$ ) affected the females' oviposition preference. Treatments with higher number eggs mass were RR2, VTPRO, VTPRO2, and $\mathrm{VTPRO}_{3}$ in plants without damaged. When considering
Fig 3 Preference of Spodoptera frugiperda larvae to feed on leaf disks (mean \pm SE) of hybrid DK390 (isogenic, blank bars), Bt hybrids (VTPRO, VTPRO2, VTPRO3), and RR2 corn hybrid (gray bars) in Petri plates. Horizontal lines represent mean standard error. NR, no response, $\chi_{2}$ test, at $5 \%$ probability.

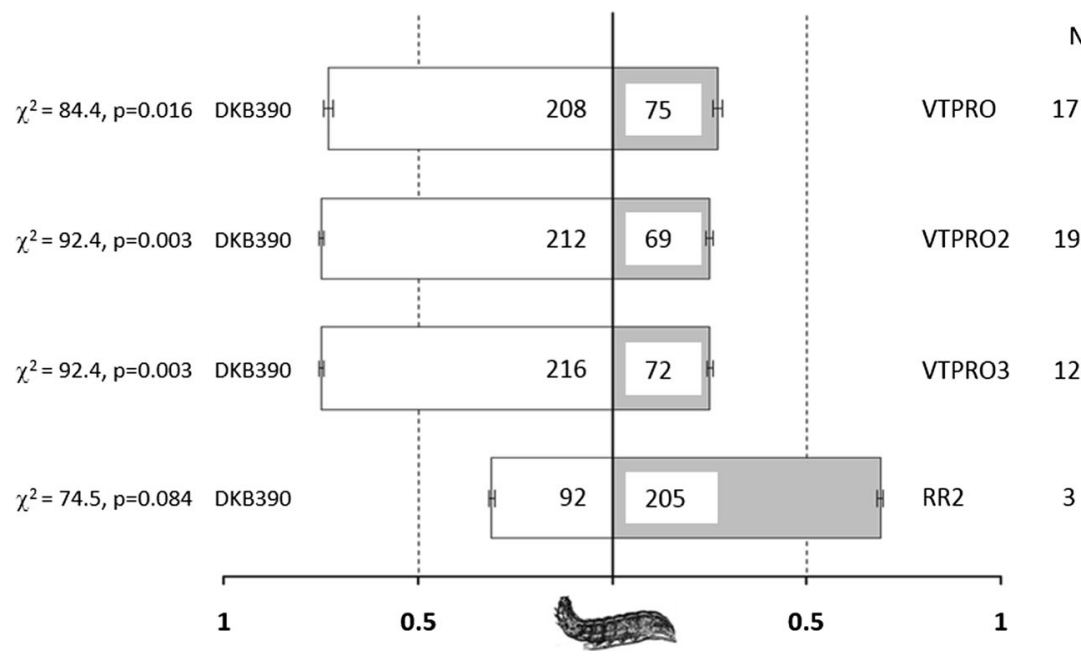



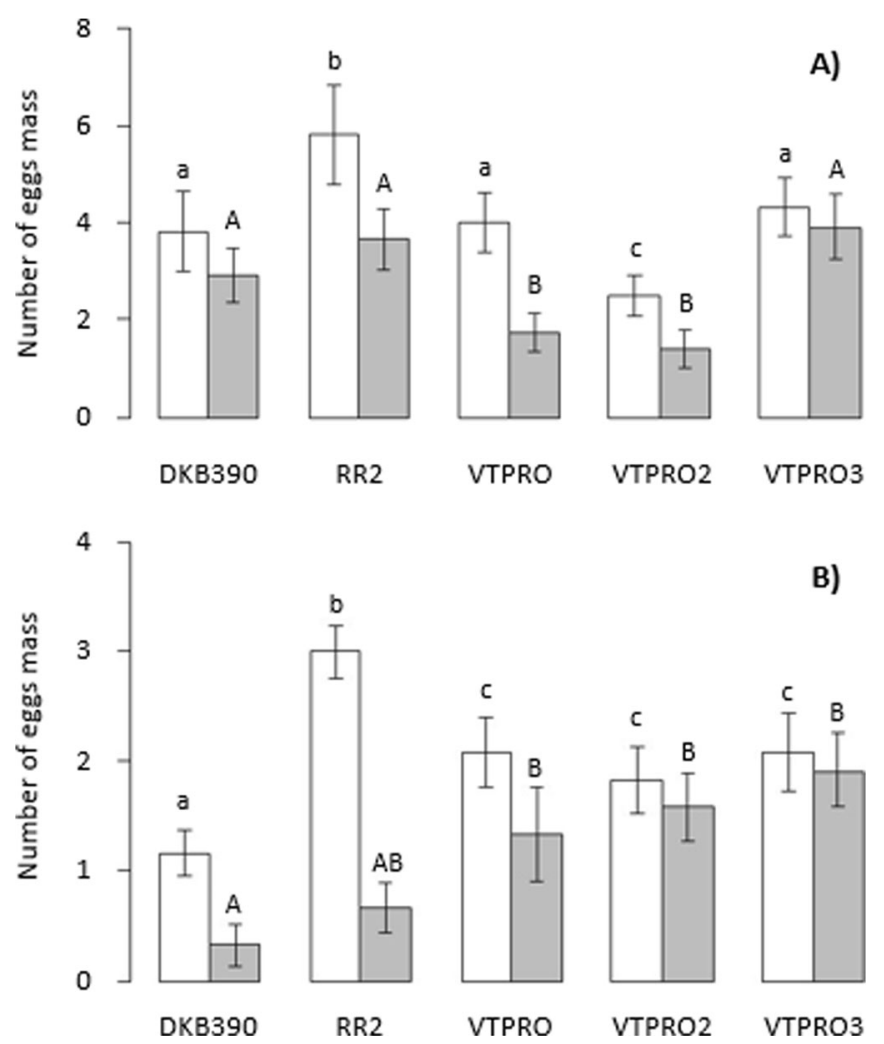

Fig 4 Number of egg masses of Spodoptera frugiperda (mean \pm SE) per plant: (A) in no-choice assay, (B) in assay with choice. Averages followed by the same letter do not differ by the Tukey test at $5 \%$ probability. Lower case letters correspond to the test on plants without damaged (white bar). Capital letters correspond to the test with damaged plants (gray bar).

damaged plants, hybrids VTPRO, VTPRO2, and VTPRO3 exhibited the largest number of egg masses and the most preferred ones.

Test for oviposition preference in the field

There was no effect on preference for oviposition in field assays with non-choice for combinations RR2 vs. isoline (Fig 5, $F_{1,15}=0.47, P=0.50$ ), VTPRO vs. isoline (Fig 5, Tukey, $F_{1,15}=1.8, P=0.20$ ), and VTPRO2 vs. isoline (Fig 5, Tukey, $F_{1}$, $15=1.03, P=0.33)$. However, combination VTPRO3 vs. isoline significantly affected the preference of the moth oviposition (Fig 5(A), Tukey, $F_{1,15}=5.06, P=0.04$ ).

Choice field experiments showed effect of hybrid, and occurred where all treatments for the moth's choice were available (Fig 5(B), Tukey, $F_{4,15}=5.424, P<0.01$ ). Singular hybrid VTPRO is the most preferred among treatments, with the largest number of egg masses per plant. Injury did not interfere in the moth's choice (Fig 5, Tukey, $F_{4,15}=3.853, P=0.06$ ).

\section{Discussion}

Larvae of S. frugiperda selected non-Bt hybrids for feeding. However, females preferred transgenic hybrids for oviposition. Therefore, there was no relationship between the preference of adult females and their offspring's good performance in our bioassays contracting what states the hypothesis that good mother knows best for their offspring (Thompson 1988).

Although some studies reported a positive relationship between larval performance and adult oviposition preference (Nylin et al 1996, Mustapha \& Myron 2003), others showed that females do not always oviposit on plant species, in which their larvae will grow and survive, or plants which performance is optimal (Thompson 1988, Robert et al 2013, De la Rosa-Cancino et al 2016, Rojas et al 2018).

Although larvae move less than moths, they displace themselves to search for adequate food, to flee cannibalism and, hence, alleviating competition for resources (Carriere 1992, Chapman et al 2000, Richardson et al 2009). The results show that $S$. frugiperda larvae preferred non-Bt corn to Bt-corn, suggesting that they might perceive the presence of an insecticide protein and that this food source is not adequate. Studies report preference for larvae of Spodoptera species based on variation in plant morphological structures such as leaf surface hair and trichomes (Yang et al 1993, Szczepaniec et al 2013). We evaluated hybrids that have the same morphological composition, but with genetic modification, suggesting that the larvae select the food 

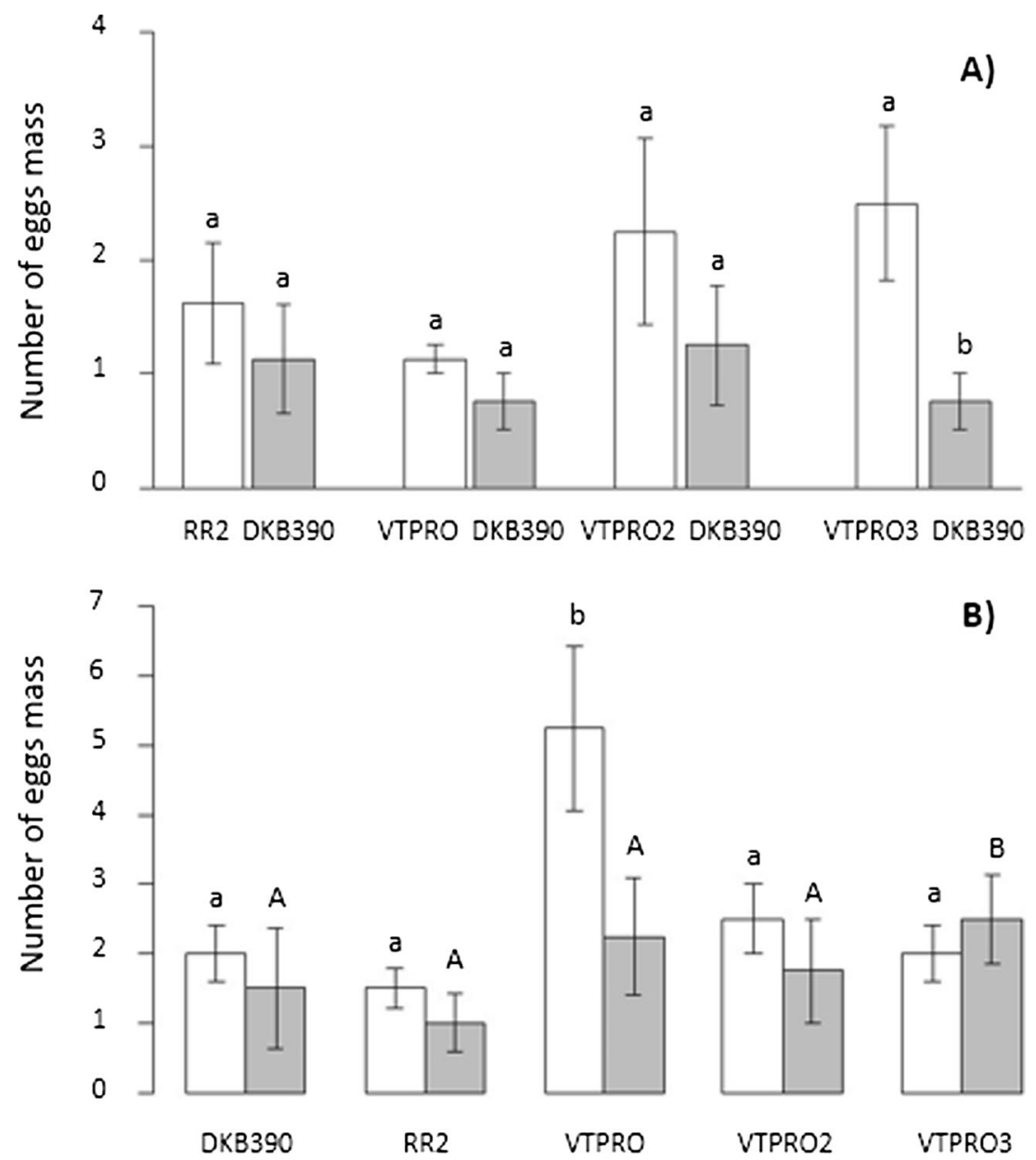

Fig 5 Number of egg masses of Spodoptera frugiperda per plant in field: (A) assays with restriction choice, RR2 vs. ISO (isoline), VTPRO vs. ISO (isoline), VTPRO2 vs. ISO (isoline) VTPRO3 vs. ISO (isoline), and (B) assay without restriction choice. Averages followed by the same letter are not significantly different according to Tukey test at $5 \%$ probability. Lower case letters correspond to the first evaluation (white bar). Capital letters correspond to the second evaluation (gray bar). Vertical lines represent mean standard error.

source by identifying the presence of Bt-proteins (Singer et al 2002).

There was no preference of larval choice between the isoline and the transgenic RR2. However, glyphosate RR2tolerant hybrid provided individuals with a longer larval period and larger pupae. It actually provided the best performance to larvae, and based on our results the singular hybrid RR2 would provide a better fitness to pests in the field if compared with the isoline, where larvae will remain for a long period feeding, generating larger adult individuals, based on pupae weight. In fact, these results suggest that the use of the herbicide-tolerant hybrid in refuge areas does not compromise the generation of susceptible individuals, since $S$. frugiperda performance in this hybrid was similar to the non-Bt hybrid.

In contrast to larvae, adult females show preference to transgenic hybrids. Hybrids RR2, VTPRO, VTPRO2, and VTPRO3 showed the highest number egg masses. Oviposition behavior of adult females may be shaped by variables other than offspring performance, nutritional quality, such as risk of parasitism or egg mortality, which may be high and differ among hosts (Thompson 1988, Schoonhoven et al 2005, Refsnider \& Janzen 2010).

Our results show that $S$. frugiperda females preferred to oviposit on Bt-hybrids with low damaged level, which release different volatiles isogenically. Several previous studies have demonstrated that the choice of sites for $S$. frugiperda oviposition is affected by volatiles of corn plants (Dean \& De moraes 2006, Penaflor et al 2011, Turlings et al 2005, Carroll et al 2006, Téllez-Rodríguez et al 2014, Hilker \& Fatouros 2015). In fact, Bt-plants release different volatiles when compared with isogenic hybrids, and moths perceive and identify these differences and select the host according to this feature (Téllez-Rodríguez et al 2014). This perception involves a co-evolution relationship between Zea mays and S. frugiperda (Musser et al 2002). Females $S$. frugiperda would avoid host plants already selected by a co-specific insect since the larvae usually compete for the whorl, the 
feeding site. Consequently, adult females would identify damaged plants, which modify the chemical profile of an isogenic since it directly interferes in the signalization for natural enemies (Fatouros et al 2012). Therefore, moths do not select damaged plants with the possibility of these plants be more attractive to predators and parasitoids. This is because the chances of survival of their offspring are low (Hellmich et al 1999, De Moraes et al 2001, Lei et al 2009). Sparks (1979) showed that the oviposition behavior of S. frugiperda changes when there are different larval densities in the plant. Consequently, one of the hypotheses of the current research has been accepted, which states that the preference of the moths for oviposition would be related to injury levels on the corn hybrid.

Studies on oviposition preference have revealed that females fail to discriminate between transgenic and conventional isogenic cultivars (Hellmich et al 1999, Torres \& Ruberson 2006, Lei et al 2009). However, these results only investigated only the number of eggs in non-injured plants or under field conditions, where other masking variables could affect the outcome, and discarded any potential effect of posterior larval feeding on the behavior of adult females. Since several Bt-crops kill small larvae immediately after hatching, food damage caused by these larvae is different from those of non-Bt crops and of other Bt technologies.

Our results may indicate several implications for resistance management in Bt crops. Moths prefer RR2 for oviposition and this factor is important to produce susceptible individuals, while injured RR2 plants are less preferred for oviposition. The use of this hybrid might be integrated with the IPM (integrated pest management), and avoid damage to all plants in the refuge area.

In conclusion, larvae and adult females of S. frugiperda select the host plant in several ways. There is a relationship between larval preference for food and adequate development. However, our data under our studied conditions showed that there is no relationship between the preference of maternal oviposition and the positive development of offspring. In addition, moths distinguished between transgenic and non-transgenic plants when infested with larvae, and the transgenic hybrids were preferred for oviposition. These results are relevant for resistance management of transgenic crops, because if individuals select Bt-crops instead of non-Bt crops, it is more likely that resistant individuals to transgenic crops will emerge due to selection pressure.

Acknowledgments The authors would like to thank the Programa de Pós-Graduação em Agronomia/Fitotecnia, for the scientific support to the student and thank Embrapa Milho e Sorgo, for the structure provided for the experiment.

Author Contribution Statement PT Nascimento planed, designed and executed experimental work, MAM Fadini conducted data analyses,
PT Nascimento wrote the manuscript. FH Valicente, MAM Fadini, CSF Souza and RG Von Pinho reviewed the manuscript.

Funding Information The study was financially supported by Conselho Nacional de Desenvolvimento Científico e Tecnológico (CNPq).

\section{References}

Bellota E, Dá vila-Flores A, Bernal JS (2017) A bird in the hand versus two in the bush? The specialist leaf-hopper Dalbulus maidis (Hemiptera: Cicadellidae) does not discriminate againstsub-optimal hostplants (Zea spp.). Neotrop Entomol 47:171-180

Bestete LR, Torres JB, Silva RBB, Silva-Torres CSA (2016) Water stress and kaolin spray affect herbivorous insects' success on cotton. Arth Plant Int 10:445-453

Bestete LR, Torres JB, Silva RBB, Silva-Torres CSA, Bastos CS (2017) Development of cotton pests exhibiting different feeding strategy on water-stressed and kaolin-treated cotton plants. J Pest Sci 90: 39-150

Carriere Y (1992) Host plant exploitation within a population of a generalist herbivore, Choristoneura rosaceana. Entomol Exp Appl 65:11-19

Carroll MJ, Schmelz EA, Meagher RL, Teal PEA (2006) Attraction of Spodoptera frugiperda larvae to volatiles from herbivore-damaged maize seedlings. J Chem Ecol 32:1911-1924

Chapman JW, Williams T, Martínez AM, Cisneros J, Caballero P, Cave RD, Goulson D (2000) Does cannibalism in Spodoptera frugiperda (Lepidoptera: Noctuidae) reduce the risk of predation? Behav Ecol Sociobiol 48:321-327

Crawley MJ (2013) The R book, 2nd edn. JohnWiley \& Sons, Chichester Cruz I, Turpin FT (1982) Efeito da Spodoptera frugiperda em diferentes estágios de crescimento da cultura do milho. Pesq Agropec Bras 17: 355-359

De la Rosa-Cancino W, Rojas JC, Cruz-Lopez L, Castillo A (2016) Attraction, feeding preference, and performance of Spodoptera frugiperda larvae (Lepidoptera: Noctuidae) reared on two varieties of maize. Environ Entomol 45:384-389

De Moraes CM, Mescher MC, Tumlinson JH (2001) Caterpillar-induced noctural plant volatiles repel conspecific females. Nature 410:577580

Dean JM, De Moraes CM (2006) Effects of genetic modification on herbivore-induced volatiles from maize. J Chem Ecol 32:713-724

Doak P (2000) Population consequences of restricted dispersal for an insect herbivore in a subdivided habitat. Ecology 81:1828-1841

Fatouros NE, Lucas-Barbosa D, Weldegergis BT, Pashalidou FG, van Loon JJ, Dicke M, Harvey JA, Gols R, Huigens ME (2012) Plant volatiles induced by herbivore egg deposition affect insects of different trophic levels. PLoS One 7:8

Head GP, Carroll MW, Evans SP, Rule DW, Willse AR, Clark TL, Storer NP, Flannagan RD, Samuel LW, Meinke $U$ (2017) Evaluation of SmartStax and SmartStax PRO maize against western corn rootworm and northern corn rootworm: efficacy and resistance management. Pest Manag Sci 73:1883-1899

Hellmich R, Higgins L, Witkowski J, Campbell J, Lewis L (1999) Oviposition by European corn borer (Lepidoptera: Crambidae) in response to various transgenic corn events. J Econ Entomol 92:1014-1020

Hilker M, Fatouros NE (2015) Plant responses to insect egg deposition. Annu Rev Entomol 60:493-515

ISAAA (2018) Global status of commercialized biotech/GM crops: 2018. https://www.isaaa.org/resources/publications/briefs/ accessed 10 Fev 2019 
Lei Z, Liu T, Greenberg S (2009) Feeding, oviposition and survival of Liriomyza trifolii (Diptera: Agromyzidae) on Bt and non-Bt cottons. Bull Entomol Res 99:3

Musser RA, Hum-Musser S, Eichenseer H, Peiffer M, Ervin G, Murphy B, Felton GW (2002) Caterpillar saliva beats plant defences: a new weapon emerges in the evolutionary arms race between plants and herbivores. Nature 416:599-600

Mustapha FAJ, Myron PZ (2003) Relationship between oviposition preference and offspring performance in Australian Helicoverpa armigera (Hübner) (Lepidoptera: Noctuidae) Aust. J Entomol 42:343-348

Nylin S, Janz N, Wedell N (1996) Oviposition plant preference and offspring performance in the comma butterfly: correlations and conflicts. Entomol Exp Appl 80:141-144

Penaflor MF, Erb M, Robert CA, Miranda LA, Werneburg AG, Alda Dossi FC, Turlings TCJ, Bento JM (2011) Oviposition by a moth suppresses constitutiveand herbivore-induced plant volatiles in maize. Planta 234:207-215

Pitre HN, Mulrooney JE, Hogg DB (1983) Fall armyworm (Lepidoptera: Noctuidae) oviposition: crop preferences and egg distribution on plants. J Econ Entomol 76:463-466

R Core Team (2014) A language and environment for statistical computing. R Foundation for statistical computing. Vienna. New Delhi, India, p 977

Refsnider JM, Janzen FJ (2010) Putting eggs in one basket: ecological and evolutionary hypotheses for variation in oviposition-site choice. Annu Rev Ecol Syst 41:39-57

Richardson ML, Mitchell RF, Reagel PF, Hanks LM (2009) Causes and consequences of cannibalism in non carnivorous insects. Annu Rev Entomol 55:39-53

Robert CAM, Erb M, Hiltpold I, Hibbard BE, Gaillard MDP, Bilat J, Degenhardt J, Cambet-Petit-Jean X, Turlings TC, Zwahlen C (2013) Genetically engineered maize plants reveal distinct costs and benefits of constitutive volatile emissions in the field. Plant Biotechnol J 11: 628-639

Rojas JC, Kolomiets MV, Bernal JS (2018) Nonsensical choices? Fall armyworm moths choose seemingly best or worst hosts for their larvae, but neonate larvae make their own choices. PLoS One 13:e0197628

Schoonhoven LM, van Loon JJA, Dicke M (2005) Insect-plant biology. Oxford University Press, New York

Schuler TH, Potting RP, Denholm I, Poppy GM (1999) Parasitoid behaviour and Bt plants. Nature 400:825-829

Signoretti AGC, Peñaflor MFGV, Bento JMS (2012) Fall armyworm, Spodoptera frugiperda (J.E. smith) (Lepidoptera: Noctuidae), female moths respond to herbivore-induced corn volatiles. Neotrop Entomol 41:22-26
Singer MS, Stireman JO (2001) How foraging tactics determine hostplant use by a polyphagous caterpillar. Oecologia 129:98-105

Singer MS, Stireman JO (2003) Does anti-parasitoid defense explain host-plant selection by a polyphagous caterpillar? Oikos 100:554-562

Singer MS, Bernays EA, Carriere Y (2002) The interplay between nutrient balancing and toxin dilution in foraging by a generalist insect herbivore. Anim Behav 64:629-643

Sparks AN (1979) A review of the biology of the fall armyworm. Fla Entomol 62:82-86

Storer NP, Kubiszak ME, Ed King J, Thompson GD, Santos AC (2012) Status of resistance to Bt maize in Spodoptera frugiperda: lessons from Puerto Rico. J Invertebr Pathol 110:294-300

Szczepaniec A, Widney SE, Bernal JS, Eubanks MD (2013) Higher expression of induced defenses in teosintes (Zea spp.) is correlated with greater resistance to fall armyworm, Spodoptera frugiperda. Entomol Exp Appl 146:242-251

Téllez-Rodríguez $\mathrm{P}$, Raymond $\mathrm{B}$, Morán-Bertot I, Rodríguez-Cabrera L, Wright DJ, Borroto CG, Ayra-Pardo C (2014) Strong oviposition preference for Bt over non-Bt maize in Spodoptera frugiperda and its implications for the evolution of resistance. BMC Biol 12:48

Thompson JN (1988) Evolutionary ecology of the relationship between oviposition preference and performance of offspring in phytophagous insects. Entomol Exp Appl 47:3-14

Torres JB, Ruberson JR (2006) Spatial and temporal dynamics of oviposition behavior of bollworm and three of its predators in Bt and nonBt cotton fields. Entomol Exp Appl 120:11-22

Turlings TCJ, Jeanbourquin PM, Held M, Degen T (2005) Evaluating the induced-odour emission of a $\mathrm{Bt}$ maize and its attractiveness to parasitic wasps. Transgenic Res 14:807-816

Udayagiri S, Mason CE (1995) Host plant constituents as oviposition stimulants for a generalist herbivore: European corn borer. Entomol Exp Appl 76:59-65

Valicente FH, Barreto MR (2003) Bacillus thuringiensis survey in Brazil: geographical distribution and insecticidal activity against Spodoptera frugiperda (J.E. Smith) (Lepidoptera: Noctuidae). Neotrop Entomol 32:639-644

Yang G, Wiseman BR, Isenhour DJ, Espelie KE (1993) Chemical and ultrastructural analysis of corn cuticular lipids and their effect on feeding by fall armyworm larvae. J Chem Ecol 19:2055-2074

Zalucki MP, Clarke AR, Malcolm SB (2002) Ecology and behavior of first instar larval Lepidoptera. Annu Rev Entomol 47:361-393

Publisher's Note Springer Nature remains neutral with regard to jurisdictional claims in published maps and institutional affiliations. 